\title{
Preparation of MgO for Removal of Dyes and Heavy Metal from Aqueous Solution: Facially Controlling the Morphology, Kinetic, Isotherms and Thermal Dynamic Investigations
}

\author{
Anh-Tuan Vu* and Van-Tu Vu \\ School of Chemical Engineering, Hanoi University of Science and Technology, Hanoi, Vietnam; \\ tuan.vuanh@hust.edu.vn,anhtu92na@gmail.com
}

\begin{abstract}
Objectives: The current study was focused on preparation of $\mathrm{MgO}$ with the different morphologies for enhanced removals of dyes and heavy metal from wastewaters. Methods/Statistical Analysis: The Mg0 samples were synthesized by a facile precipitation method with the calcination temperature of $500^{\circ}$, its morphology was controlled by altering the concentration of $\mathrm{K}_{2} \mathrm{CO}_{3}$ and $\mathrm{Mg}\left(\mathrm{NO}_{3}\right)_{2}$. As-prepared samples were characterized by TGA, XRD, $\mathrm{N}_{2}$ adsorption/desorption isotherm, FT-IR, FE-SEM and TEM. The performance of as-prepared MgO samples was evaluated by adsorptions of dyes and leads (II) and compared to those of commercial $\mathrm{MgO}$ (CM-MgO) and Activated Carbon (AC). Findings: Flower-like MgO (F-MgO) had the high surface area and pore volume $\left(232 \mathrm{~m}^{2} / \mathrm{g}\right.$ and $0.575 \mathrm{~cm}^{3} / \mathrm{g}$, respectively) as compared to rod-like $\mathrm{MgO}$ (R-Mg0) and $\mathrm{CM}-\mathrm{MgO}$. The adsorption rate and adsorption capacity of tartrazine on F-MgO were faster and larger, respectively, than those of $\mathrm{R}-\mathrm{MgO}, \mathrm{CM}-\mathrm{MgO}$ and $\mathrm{AC}$. The adsorption of F-MgO was achieved equilibrium in $15 \mathrm{~min}$ and the adsorption capacity was $65.8 \mathrm{mg} / \mathrm{g}$ at the $\mathrm{MgO}$ dosage of $0.12 \mathrm{~g}$, initial tartrazine concentration of $50 \mathrm{mg} / \mathrm{L}$, solution $\mathrm{pH}$ of 7.0, and temperature of $30^{\circ} \mathrm{C}$. The adsorption rate was followed the pseudo second equation and the rate constant was $0.02 \mathrm{~g}^{\mathrm{mg}} \mathrm{mg}^{-1} \cdot \mathrm{min}^{-1}$ at $30^{\circ} \mathrm{C}$. The heat of adsorption $\left(\Delta \mathrm{H}^{\circ}=19.48 \mathrm{~kJ} / \mathrm{mol}\right)$ confirmed the exothermic adsorption of tartrazine and the negative values of $\mathrm{G}^{\circ}$ indicatedthe spontaneous adsorption. The removal efficiency of tartrazine was gradually decreased, but it still remained at $95.2 \%$ for the fifth cyclic experiment. In addition, the removal efficiency of $\mathrm{Pb}$ (II) on $\mathrm{MgO} / \operatorname{tartrazine}(95 \%)$ was much larger than that of F-MgO (about 10\%). Application/Improvements: This study gives promising results in concern with treatment of industrial wastewaters before they are charged into the environment.
\end{abstract}

Keywords: Adsorption, Dye, Heavy Metal, MgO, Wastewater

\section{Introduction}

The development of various industries, such as dying, metallurgy, battery manufacturing, chemical, electroplating and other industries, leads a huge amount of wastewater containing different types of toxic dyes and heavy metal ions. It is almost emitted to the environment without appropriate treatment causing seriously environmental pollution ${ }^{1,2}$. Currently, scientists and government very concern about the problem of wastewater treatment before it is released into the environment.
Synthetic dyes are typical pollutant causing environmental and health problems. Most of them are toxic, even carcinogenic and this poses a serious hazard for human being and aquatic animals ${ }^{3}$. To decrease impact of dyes on the environment, various treatment methods such as adsorption, Advanced Oxidation Process (AOP), bio degradation, and ion exchanged have been developed ${ }^{4}$. Among these methods, adsorption is widely used for removing dyes due to its simplicity and high efficiency. In each adsorption process, the adsorbent behavior plays a very important role. Particularly, metal oxides have been

*Author for correspondence 
showed as the effective materials for the removal of dye pollutants because of its excellent physical properties such as large surface area, high pore volume, large numbers of highly reactive edges, thermal and mechanical strengths ${ }^{\underline{5}}$.

Lead, a heavy metal, contains the most serious problem for environment due to its typical characteristic of persistence, easy migration, bio-accumulation and bio-toxicity ${ }^{\underline{6}}$. As a result, it can take the place of other microelements, and disrupt or stop normal biochemical reactions in the body. For pregnant women, lead buildup in the body competing with calcium in bones. It can surpass the placental barrier, exposure to the baby leading reduced fetal growth then result the risk of preterm birth. In case of adults, exposure to lead for a long time is also noted on the cardiovascular system such as hypertension, memory loss, and cancer ${ }^{7}$. Therefore, an urgent task need to effectively removal of lead in wastewater so that its concentration is reduced to the permitted level. In order to remove lead, many methods have been developed such as ion exchange treatments ${ }^{8}$, reverse osmosis filtration ${ }^{9}$, membrane filtration ${ }^{10}$, electro-chemistry ${ }^{11}$, solar-photo-voltaic and electro-coagulation $\underline{12}$. However, these methods have the unavoidable disadvantages such high cost, complexity and difficult to operate.

Magnesium oxide $(\mathrm{MgO})$ is one of the promising adsorbents because it is abundant, nontoxic, and environmentally friendly material with high specific surface area and easy regeneration ${ }^{13}$. $\mathrm{MgO}$-based materials have been reported that as the effective sorbents for removal of dyes. $\mathrm{MgO}$ prepared by using PVP as an inhibited growth of crystallites could removal of Levafix Fast Red (LFR) CA and indanthrene blue (IB) BC, the adsorption capacities were 92.16 and $86.50 \mathrm{mg} / \mathrm{g}$ in $60 \mathrm{~min}$ for LFR and IB, respectively ${ }^{5}$. The sorption capacity of methylene blue on the nano $\mathrm{Ni}-\mathrm{MgO}$ prepared by using a non-ionic block copolymer (Pluronic F-127) as surfactant could reach 637 $\mathrm{mg} / \mathrm{g}$ at the high concentration of dye $\mathrm{e}^{\underline{14}}$. The addition of $\mathrm{Fe}_{2} \mathrm{O}_{3}$ into $\mathrm{MgO}$ could improve the adsorption capacity of remazol red RB-133, $43.7 \mathrm{mg} / \mathrm{g}$ within $19 \mathrm{~min}^{15}$. The $\mathrm{MgO} /$ chitosan composite prepared by chemical precipitation method was use for adsorption of methyl orange and antibacterial $\frac{16}{}$. And, $\mathrm{MgO}$ prepared by hydrothermal method showed the high adsorption capacities of reactive blue and reactive ${ }^{17}$.

It is important to note that the textural and physical properties of materials were strongly depended on preparation method. In order to preparation of $\mathrm{MgO}$ with high surface area and large pore volume, the aero gel method has been developed with the 4-step calcinations procedure $\frac{13,18,19}{19}$. But high pressure and temperature, expensive solvents, and low production to prepare the samples were limitations for practical applications.

The present study focused one preparation of $\mathrm{MgO}$ samples with the different morphologies for enhanced removals of tartrazine and $\mathrm{Pb}$ (II). The performance of samples was evaluated by adsorption of tartrazine in batch mode reactor. The effects of reaction parameters on adsorption of tartrazine, kinetic, isotherm, and thermodynamic adsorption were investigated. In addition, the reusability of F-MgO was evaluated. After adsorption of tartrazine, $\mathrm{MgO} /$ tartrazine sample was used to further adsorb $\mathrm{Pb}$ (II).

\section{Experimental}

\subsection{Materials}

Tartrazine (analytical standard) was purchased from Sigma-Aldrich, its chemical structure and the basic physical properties are shown Table 1. The dye solution 2000 $\mathrm{mg} / \mathrm{L}$ prepared by dissolving $0.5 \mathrm{~g}$ dyes powder in 250 $\mathrm{mL}$ double distilled water was used as the stock solution, it was diluted to the desired concentration throughout experiments. The $\mathrm{Mg}\left(\mathrm{NO}_{3}\right)_{2} \cdot 6 \mathrm{H}_{2} \mathrm{O}(99 \%), \mathrm{K}_{2} \mathrm{CO}_{3}(99 \%)$, $\mathrm{Pb}\left(\mathrm{NO}_{3}\right)_{2}(99.5 \%)$, commercial $\mathrm{MgO}$ (CM-MgO, $\left.99 \%\right)$, and Activated Carbon (AC) were purchased from Merck.

Table 1. Basic properties of tartrazine

\begin{tabular}{|l|l|}
\hline Chemical formula & $\mathrm{C}_{16} \mathrm{H}_{9} \mathrm{~N}_{4} \mathrm{Na}_{3} \mathrm{O}_{9} \mathrm{~S}_{2}$ \\
\hline Chemical class & $\mathrm{AzO}$ \\
\hline $\begin{array}{l}\text { Molecular weight } \\
(\mathrm{g} / \mathrm{mol})\end{array}$ & 534.4 \\
\hline$\lambda_{\max }(\mathrm{nm})$ & 428 \\
\hline C.I. number & 19140 \\
\hline Nature & Anion dye \\
\hline $\begin{array}{l}\text { Molecular } \\
\text { structure }\end{array}$ & \\
\hline
\end{tabular}

\subsection{Preparation of MgO Samples}

Preparation of F-MgO: In a typical synthesis, aqueous $\mathrm{K}_{2} \mathrm{CO}_{3}$ solution $(20 \mathrm{~mL}, 0.5 \mathrm{M})$ was added drop-wise to aqueous $\mathrm{Mg}\left(\mathrm{NO}_{3}\right)_{2}$ solution $(100 \mathrm{~mL}, 0.1 \mathrm{M})$ in a beaker 
under vigorous stirring to form white precipitate for $1 \mathrm{~h}$ at room temperature. The temperature was increased to $80^{\circ} \mathrm{C}$ and remained at this temperature for $3 \mathrm{~h}$. The precipitate was filtered by double distilled water. After drying at $80^{\circ} \mathrm{C}$ for $12 \mathrm{~h}$, the sample was claimed by ramp the temperature to $500^{\circ} \mathrm{C}$ at the heating rate of $1^{\circ} \mathrm{C} /$ minand maintaining for $9 \mathrm{~h}$ under air condition to obtain flowerlike $\mathrm{MgO}$.

Preparation of $\mathrm{R}-\mathrm{MgO}$ : The concentrations of precursors were increased, aqueous $\mathrm{K}_{2} \mathrm{CO}_{3}$ solution $(50 \mathrm{~mL}, 1 \mathrm{M})$ was added drop-wise to aqueous $\mathrm{Mg}\left(\mathrm{NO}_{3}\right)_{3}$ solutions (100 $\mathrm{mL}, 0.5 \mathrm{M}$ ) under vigorous stirring to form white precipitate. Subsequently, the same procedure with $\mathrm{F}-\mathrm{MgO}$ was used to preparerod-lile $\mathrm{MgO}$.

\subsection{Characterization of Materials}

Phase composition was crystal structure of samples were examined by X-Ray power Diffraction (XRD). XRD patterns were obtained by using Bruker D8 Ax XRDdiffractometer (Germany) with $\mathrm{Cu} K \alpha$ irradiation $(40 \mathrm{kV}$, $40 \mathrm{~mA}$ ). The $2 \theta$ ranging from 20 to $70^{\circ}$ was selected to analyse the crystal structure. The Transmission Electron Microscopy (TEM) and Field Emission Scanning Electron Microscopy (FE-SEM) were analyzed by the JEM-2010 and JEOL-7600F instruments, respectively, to observe the morphology and size of the samples. The $\mathrm{N}_{2}$ adsorption/desorption isotherm was analyzed by an AutosorbiQ, version 3.0 analyzer. Fourier Transform Infrared Spectroscopy (FT-IR) was recorded in the wave range of $4000-400^{\circ} \mathrm{cm}^{-1}$ by aninstrument VERTEX 70 . The decomposition of powder before calcination was performed using a thermo-gravimetric analyzer (TGA, Versa Thermal Instrument).

\subsection{Adsorption Experiment}

In a batch test, the dye stock solution was diluted to prepared $50 \mathrm{~mL}$ dye solution at desired concentration; $\mathrm{pH}$ solution was adjusted by $0.1 \mathrm{M} \mathrm{HCl}$ and $\mathrm{NaOH}$ solutions. A known amount of adsorbent was then added and the resulting suspension was kept under constant agitation $(300 \mathrm{rpm})$. At the given time intervals, an amount of analytical sample $(\sim 2 \mathrm{~mL})$ was withdrawn from the mixture and immediately filtered through a syringe filter $(0.45 \mu \mathrm{m}$ PTFE membrane). The remaining dye concentration was analysed by a UV-Vis spectrophotometer (Agilent 8453) at $428 \mathrm{~nm}$. The equilibrium sorption capacity (qe) and the Removal efficiency (Re) were determined by following equations:

$$
\begin{gathered}
q_{e}=\frac{\left(C_{o}-C_{e}\right) \times v}{m} \\
R_{e}=\frac{C_{O}-C_{t}}{C_{O}} \times 100 \%
\end{gathered}
$$

Where $\mathrm{C}_{\mathrm{o}}(\mathrm{mg} / \mathrm{L})$ is the initial dye concentration, $\mathrm{C}_{\mathrm{e}}(\mathrm{mg} / \mathrm{L})$ is the dye concentration at equilibrium, and $C_{t}(\mathrm{mg} / \mathrm{L})$ is the concentrations at adsorption time $\mathrm{t}, \mathrm{V}$ is the volume of dye solution $(\mathrm{L}), \mathrm{m}$ is the mass of the adsorbent $(\mathrm{g})$.

To evaluate the adsorption ability of heavy metal on $\mathrm{MgO} /$ tartrazine, we selected the lead (II) for the experiment. The reactor containing $100 \mathrm{~mL}$ of tartrazine $50 \mathrm{mg} / \mathrm{L}$ was adjusted at $\mathrm{pH}$ to 6.0 . The F-MgO sample $(0.12 \mathrm{~g})$ was added into solution and stirred at $300 \mathrm{rpm}$ in $30 \mathrm{~min}$. Then, $10 \mathrm{~mL}$ of $\mathrm{Pb}$ (II) $500 \mathrm{mg} / \mathrm{L}$ was added into reactor. At given time intervals, an aliquot $(2 \mathrm{~mL})$ solution was withdrawn from the suspension and immediately filtered by a syringe filter $(0.45 \mu \mathrm{m}$ PTFE membrane). The $\mathrm{Pb}$ (II) concentration of the filtrate was analyzed by an atomic absorption spectrometer (Analytik Jena AG, Germany).

\subsection{Adsorption Isotherms}

Adsorption isotherms were carried by adding the certain amount of $\mathrm{MgO}(0.12 \mathrm{~g})$ to the reactor containing 100 $\mathrm{mL}$ of tartrazine solution with the concentration range of 20-60 mg/L, at $\mathrm{pH}=7.0$, room temperature and stirring in $15 \mathrm{~min}$. The following models were used to analyse the adsorption equilibrium.

The Langmuir isotherm equation assumes that the sorption is localized in a monolayer and there is no interaction between the adsorbate molecules ${ }^{20}$. The linear form of Langmuir equation is:

$$
\frac{C_{e}}{q_{e}}=\frac{C_{e}}{q_{\max }}+\frac{1}{k_{L} q_{\max }}
$$

Where $\mathrm{C}_{\mathrm{e}}(\mathrm{mg} / \mathrm{L})$ is the concentration at equilibrium, $\mathrm{q}_{\mathrm{e}}$ $(\mathrm{mg} / \mathrm{g})$ is equilibrium adsorption capacity, $\mathrm{q}_{\max }(\mathrm{mg} / \mathrm{g})$ is maximum adsorption capacity, $\mathrm{k}_{\mathrm{L}}(\mathrm{L} / \mathrm{mg})$ is the Langmuir constant. The values of $\mathrm{k}_{\mathrm{L}}$ and $\mathrm{q}_{\max }$ were determined by intercept and slope of the linear plot of $\frac{C_{e}}{q_{e}}$ versus $\mathrm{C}_{e}$.

The Freundlich adsorption model assumes that adsorption takes place on heterogeneous surfaces ${ }^{21}$. The linear form of Freundlich equation is:

$$
\ln q_{e}=\ln k_{F}+\frac{1}{n} \ln C_{e}
$$


Where $\mathrm{k}_{\mathrm{F}}$ and $1 / \mathrm{n}$ are characteristic constants representing to adsorption capacity and the adsorption intensity, respectively. The values of $n$ and $\mathrm{k}_{\mathrm{F}}$ can be determined from plot of $\operatorname{lnq}_{e}$ versus $\ln C_{e}$.

The Temk in isotherm model takes into account adsrobate-adsorbent interactions assumes that the heat of adsorption decreases linearly with the coverage ${ }^{22}$. The Temkin equation is:

$$
q_{e}=\beta \ln \alpha+\beta \ln C_{e}
$$

where $\beta=\frac{R T}{b}(\mathrm{j} / \mathrm{mol})$ is the constant related to heat of adsorption, $\mathrm{q}_{\mathrm{e}}(\mathrm{mg} / \mathrm{g})$ is the sorption capacity at equilibrium, and $\mathrm{C}_{e}(\mathrm{mg} / \mathrm{L})$ is the concentration of dyes at equilibrium, $\alpha(\mathrm{L} / \mathrm{mg})$ is the equilibrium binding constant corresponding to the maximum binding energy, $b(\mathrm{~J} /$ $\mathrm{mg}$ ) is the Temkin constant related to heat of adsorption. $\mathrm{R}\left(8.314 \mathrm{~J} \cdot \mathrm{mol}^{-1} \cdot \mathrm{L}^{-1}\right.$ and $\mathrm{T}(\mathrm{K})$ are universal gas constant and absolute temperature, respectively. The $\alpha$ and $\beta$ values can be calculated from plot of $\mathrm{q}_{e}$ versus $\ln \mathrm{C}_{e}$.

The Dubinin-Radushkevich (D-R) isothermmodel is generally applied to distinguish the physical or chemical adsorption ${ }^{23}$. The linear form of $\mathrm{D}-\mathrm{R}$ equation is:

$$
\ln \left(q_{e}\right)=\ln \left(Q_{m}\right)-K \varepsilon^{2}
$$

Where $\mathrm{K}$ is a Dubinin-Radushkevich constant $\left(\mathrm{mol}^{2} / \mathrm{kJ}^{2}\right)$, $\mathrm{Q}_{\mathrm{m}}(\mathrm{mg} / \mathrm{g})$ is the theoretical adsorption capacity, $\varepsilon$ is the Polanyi potential, which can be determined by using following equation:

$$
\varepsilon=\mathrm{RT} \ln \left(1+\frac{1}{C_{e}}\right)
$$

The $\mathrm{Q}_{\mathrm{m}}$ and $\mathrm{K}$ values can determined from of plot of $\ln \left(\mathrm{q}_{\mathrm{e}}\right)$ versus $\varepsilon^{2}$. The mean sorption energy $\mathrm{E}(\mathrm{kJ} / \mathrm{mol})$ was calculated as follow:

$$
E=\frac{1}{\sqrt{2 \cdot K}}
$$

The $\mathrm{E}$ value distinguishes the chemical or physical adsorption. The value of $\mathrm{E}<8 \mathrm{~kJ} / \mathrm{mol}$ the adsorption process was physical in nature, and if in the range of $8-16 \mathrm{~kJ} / \mathrm{mol}$ the adsorption process flows by chemical ion-exchange, whereas if the value is more than $16 \mathrm{kj} / \mathrm{mol}$ the adsorption process is chemical adsorption in nature ${ }^{24}$.

\subsection{Adsorption Kinetics}

The study of chemical kinetics can provide important information on adsorption rate and the factors affecting the sorption rate $e^{25}$. In order to investigate the mechanism of dye adsorption on $\mathrm{MgO}$, the following models were use.
The pseudo-first-order equation:

$$
\ln \left(q_{e}-q_{t}\right)=\ln q_{e}-k_{1}
$$

Where $\mathrm{q}_{\mathrm{e}}$ and $\mathrm{q}_{\mathrm{t}}$ are the adsorption amount of tartrazine $(\mathrm{mg} / \mathrm{g})$ at time $\mathrm{t}$ and equilibrium, respectively, $\mathrm{k}_{1}\left(\mathrm{~min}^{-1}\right)$ is the rate constant. The values of andcan be determinedfrom the plot of $\ln \left(\mathrm{q}_{\mathrm{e}}-\mathrm{q}_{\mathrm{t}}\right)$ versus $\mathrm{t}$.

The pseudo-second-order kinetic model:

$$
\frac{t}{q_{t}}=\frac{1}{k_{2} q_{e}^{2}}+\frac{t}{q_{e}}
$$

Where $\mathrm{k}_{2}\left(\mathrm{~g} \cdot \mathrm{mg}^{-1} \cdot \mathrm{min}^{-1}\right)$ is the rate constant. The values of $\mathrm{q}_{\mathrm{e}}$ and $\mathrm{k}_{2}$ can be determined from the plot oft/ $\mathrm{q}_{\mathrm{t}}$ versus $\mathrm{t}$.

The kinetics were also analysed by Weber-Morri' equation model to understand the diffusion mechanism. This model is significant to know the rate step in the liquid adsorption systems and gain further insight into the adsorption behaviour of dyes on $\mathrm{MgO}$. The equation is:

$$
q_{t}=k_{i} t^{0.5}+C
$$

Where $\mathrm{k}_{\mathrm{i}}\left(\mathrm{mg} \cdot \mathrm{g}^{-1} \cdot \mathrm{min}^{-0.5}\right)$ is intra-particle diffusion rate constant and $\mathrm{C}$ is the thickness of boundary layer. The $\mathrm{k}_{\mathrm{i}}$ and $C$ values can be determined from the plot of $q_{t}$ versus $t^{0.5}$. The larger $C$ implies the greater effect of the boundary layer. According to model, the adsorption process is controlled by intra-particle diffusion model if the plot of $\mathrm{q}_{\mathrm{t}}$ versus $\mathrm{t}^{0.5}$ is a straight line passing through the origin with $\mathrm{C}=0$.

Elovich model indicating absorbing surface is heterogeneous gives in following form ${ }^{26}$ :

$$
q_{t}=\frac{\ln (\alpha \beta)}{\beta}+\frac{\ln t}{\beta}
$$

Where $\alpha\left(\mathrm{mg} \cdot \mathrm{g}^{-1} \cdot \mathrm{min}^{-1}\right)$ is the initial adsorption rate and $\beta$ is the desorption constant ( $\mathrm{g} / \mathrm{mg}$ ). The values of $\alpha$ and $\beta$ were computed from plot of $\mathrm{q}_{\mathrm{t}}$ versus lnt.

\subsection{Adsorption Thermodynamic}

The adsorption of tartrazine on $\mathrm{MgO}$ was carried out at three different temperatures 30,40 and $50^{\circ} \mathrm{C}$. The values of thermodynamic parameters such as standard enthalpy $\left(\Delta \mathrm{H}^{\circ}\right)$, standard entropy $\left(\Delta \mathrm{S}^{\circ}\right)$, and standard free energy $\left(\Delta \mathrm{G}^{\circ}\right)$ is calculated by using the following equations:

$$
\begin{aligned}
\Delta G^{\circ} & =-R T \ln k_{c} \\
k_{c} & =\frac{q_{e}}{C_{e}} \\
\ln k_{c} & =-\frac{\Delta H^{\circ}}{\text { R.T }}+\frac{\Delta S^{\circ}}{R}
\end{aligned}
$$


Where $\mathrm{k}_{\mathrm{c}}$ is the equilibrium constant $\mathrm{R}$ is the gas constant (8.314J. $\left.\mathrm{mol}^{-1} \cdot \mathrm{L}^{-1}\right)$, and $\mathrm{T}$ is the absolute temperature $(\mathrm{K})$. The values of $\Delta \mathrm{H}^{\circ}$ and $\Delta \mathrm{S}^{\circ}$ can be obtained by plotting $\operatorname{lnk}_{\mathrm{c}}$ versus $\mathrm{T}$.

\section{Results and Discussion}

\subsection{Characterization}

Figure 1(a) shows the TGA/DTG curves of the sample before calcination. The absorbed water was lost below or near $100^{\circ} \mathrm{C}$. The weight loss from 130 to $350^{\circ} \mathrm{C}$ observed in the TGA curve corresponding to a sharp peak in DTG curve at 288 could be assigned to emission of water of crystallization. In addition, the weight loss between 360 and $520^{\circ} \mathrm{C}$ could come from the emission of hydroxyl water and carbon dioxide. This result implied that the sample before calcination was completely decomposed at the higher temperature than $489^{\circ} \mathrm{C}$, therefore the calcination temperature of $500^{\circ} \mathrm{C}$ was selected in this studied.

The XRD patterns of sample before calcination, $\mathrm{F}-\mathrm{MgO}, \mathrm{R}-\mathrm{MgO}$ and $\mathrm{CM}-\mathrm{MgO}$ are presented in Figure 1(b). The diffraction peaks of the sample before calcination belonged to $\mathrm{Mg}_{5}(\mathrm{OH})_{2}\left(\mathrm{CO}_{3}\right)_{4} \cdot 4 \mathrm{H}_{2} \mathrm{O}$ (JCPDS data No. 25-0513 $)^{27}$. X-ray diffraction peaks corresponding to the (111), (200), and (220) planes were observed in all the $\mathrm{MgO}$ samples and other impurity peaks were not detected indicating that the pure phase of $\mathrm{MgO}$ (JCPDS data No. 78-0430) $)^{\frac{13}{3}}$ was obtained via thermal decomposition of the $\mathrm{Mg}_{5}\left(\mathrm{CO}_{3}\right)_{4}(\mathrm{OH})_{2} .4 \mathrm{H}_{2} \mathrm{O}$ at $500^{\circ} \mathrm{C}$. The diffraction peaks of $\mathrm{F}-\mathrm{MgO}$ were less intensity than those of $\mathrm{R}-\mathrm{MgO}$ and $\mathrm{CM}-\mathrm{MgO}$. These results implied that F-MgO crystals were less ordered than CM-MgO. The crystallite sizes $\left(\mathrm{D}_{c^{\prime}}\right.$ $\mathrm{nm}$ ) of MgO samples were calculated from the (200) diffraction peak by using the Scherrer equation ${ }^{13}$.

$$
D_{\text {XRD }}=\frac{K \lambda}{B \cos \theta}
$$

Where $\mathrm{K}$ is a dimensionless constant ( 0.94 for a cubic crystal $\mathrm{MgO}$ ), $\theta$ and $\mathrm{B}$ variables are the angles between the incident and diffracted beam and the line broadening at half the maximum ( $\mathrm{rad}$ ) respectively. As the results, the crystallite sizes of $\mathrm{F}-\mathrm{MgO}, \mathrm{R}-\mathrm{MgO}$, and $\mathrm{CM}-\mathrm{MgO}$ were $8.6,9,6$ and $12.3 \mathrm{~nm}$, respectively, in Table 2.
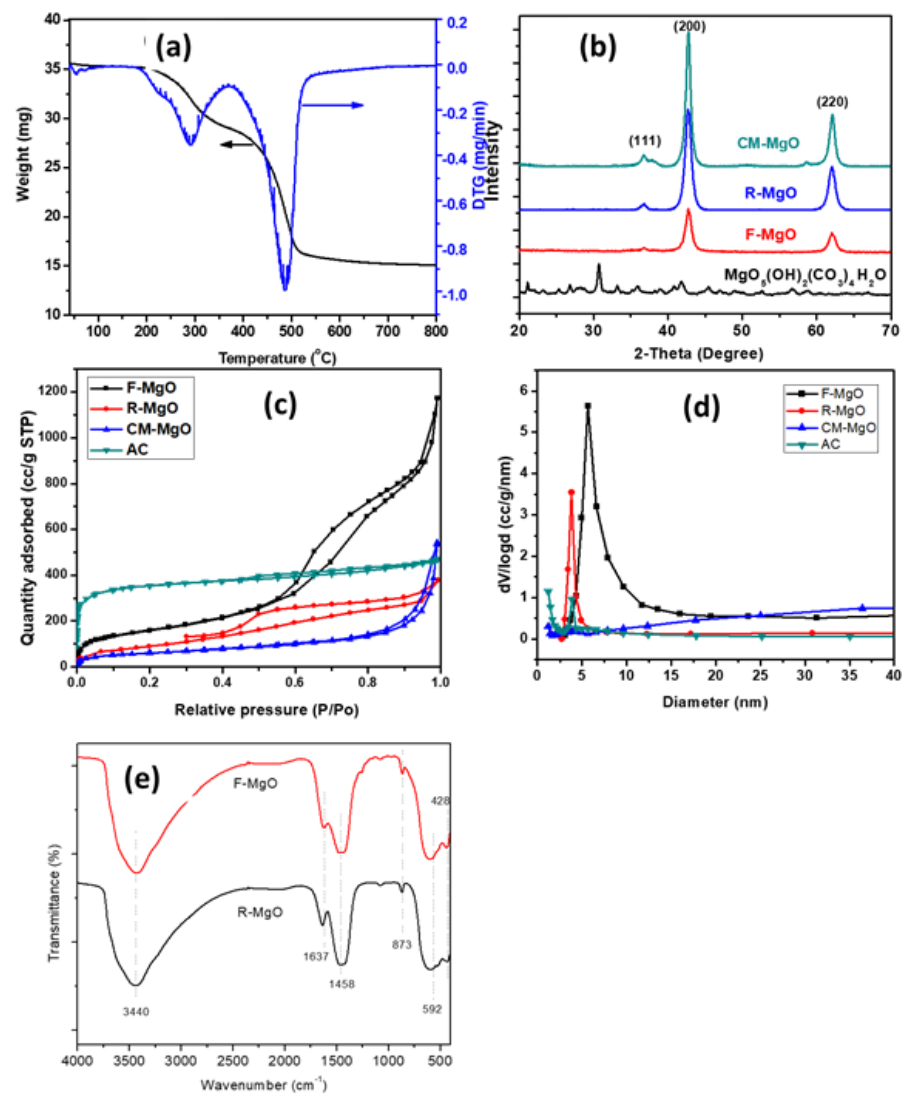

Figure 1. (a) TGA/DTG profile of sample before calcination; (b) XRD patterns of the sample before calcination, F-MgO, $\mathrm{R}-\mathrm{MgO}$ and $\mathrm{CM}-\mathrm{MgO}$; (c) and (d) $\mathrm{N}_{2}$ adsorption/desorption isotherms and pore size distributions of the $\mathrm{MgO}$ samples and AC; (e) FT-IR spectra of as-synthesized of $\mathrm{MgO}$ samples. 
Table 2. Textural properties of F-MgO, R-MgO, $\mathrm{CM}-\mathrm{MgO}$ and $\mathrm{AC}$

\begin{tabular}{|l|c|c|c|c|c|}
\hline Sample & $\begin{array}{c}\mathbf{S}_{\mathrm{BET}} \\
\left(\mathbf{m}^{2} / \mathbf{g}\right)\end{array}$ & $\begin{array}{c}\mathbf{V}_{\text {Pore }} \\
\left(\mathbf{c m}^{3} / \mathbf{g}\right)\end{array}$ & $\begin{array}{c}\text { Average pore } \\
\text { diameter } \\
(\mathbf{n m})\end{array}$ & $\begin{array}{c}\mathbf{D}_{\mathbf{c}} \\
(\mathbf{n m})\end{array}$ & $\begin{array}{c}\mathbf{D}_{\text {вЕT }} \\
(\mathbf{n m})\end{array}$ \\
\hline $\mathrm{F}-\mathrm{MgO}$ & 232 & 0.575 & 9.3 & 8.6 & 7.3 \\
\hline $\mathrm{R}-\mathrm{MgO}$ & 145 & 0.263 & 7.0 & 9.6 & 11.7 \\
\hline $\begin{array}{l}\mathrm{CM}- \\
\mathrm{MgO}\end{array}$ & 103 & 0.421 & 15.9 & 12.3 & 16.4 \\
\hline $\mathrm{AC}$ & 1063 & 1.06 & 1.20 & - & - \\
\hline
\end{tabular}

Figures 1(c-d) presents the $\mathrm{N}_{2}$ adsorption/desorption isotherms and pore size distributions of the $\mathrm{MgO}$ samples and AC. The isotherm of AC was classified as a type I according to IUPAC classification, implying a micro-porous material with a small average pore diameter $(1.20 \mathrm{~nm})$ in Table 2. While, the isotherm curves of $\mathrm{MgO}$ samples were classified as type II with the $\mathrm{H}_{4}$ hysteresis loop indicating mesoporous materials. The surface area was in following order: AC $\left(1063 \mathrm{~m}^{2} / \mathrm{g}\right)>\mathrm{F}-\mathrm{MgO}\left(232 \mathrm{~m}^{2} / \mathrm{g}\right)>\mathrm{R}-\mathrm{MgO}(145$ $\left.\mathrm{m}^{2} / \mathrm{g}\right)>\mathrm{CM}-\mathrm{MgO}\left(103 \mathrm{~m}^{2} / \mathrm{g}\right)$. The theoretical particle size was also calculated from BET surface area, assuming a spherical particle, form the following equation:

$$
D_{\text {BET }}=\frac{6000}{\rho \times s}
$$

Where $\mathrm{D}_{\mathrm{BET}}$ is the equivalent particle diameter in nanometer, $\rho$ is the density of $\mathrm{MgO}\left(3.58 \mathrm{~g} / \mathrm{cm}^{3}\right)^{\frac{13}{3}}$, and $\mathrm{S}$ is the BET surface area $\left(\mathrm{m}^{2} / \mathrm{g}\right)$. As the results, the particle sizes of F-MgO, R-MgO and CM-MgO were 7.3, 11.7 and 16.4 $\mathrm{nm}$, respectively.

The pore size distribution of $\mathrm{CM}-\mathrm{MgO}$ was relative broad. As seen in Table 2, the pore volume and average pore diameter of $\mathrm{CM}-\mathrm{MgO}$ was $0.421 \mathrm{~cm}^{3} / \mathrm{g}$ and 15.9 $\mathrm{nm}$, respectively. The pore size distribution $\mathrm{R}-\mathrm{MgO}$ was higher intensity than $\mathrm{AC}$, but both samples concentrated on 2.5-5 nm. The pore volumes of $\mathrm{R}-\mathrm{MgO}$ and $\mathrm{AC}$ were 0.263 and $1.06 \mathrm{~cm}^{3} / \mathrm{g}$, respectively. The pore size distribution of the $\mathrm{F}-\mathrm{MgO}$ sample was broader and concentrated at larger size than those of $\mathrm{R}-\mathrm{MgO}$ and $\mathrm{AC}$, the pore volume was $0.575 \mathrm{~cm}^{3} / \mathrm{g}$.

Figure 1 (e) shows the FT-IR spectra of the as-prepared $\mathrm{MgO}$ samples. The sharp peak around $3400 \mathrm{~cm}^{-1}$ for as-prepared $\mathrm{MgO}$ corresponds to the free hydroxyl group $\mathrm{OH}^{-}$stretching model $\frac{15}{}$. The bending modes of the adsorbed water molecules appear as a weak band around $1637 \mathrm{~cm}^{-1}$. A broad band at $1510-1480 \mathrm{~cm}^{-1}$ corresponds to the $\mathrm{Mg}-\mathrm{O}$ stretching vibration and the $\mathrm{Mg}-\mathrm{O}-\mathrm{Mg}$
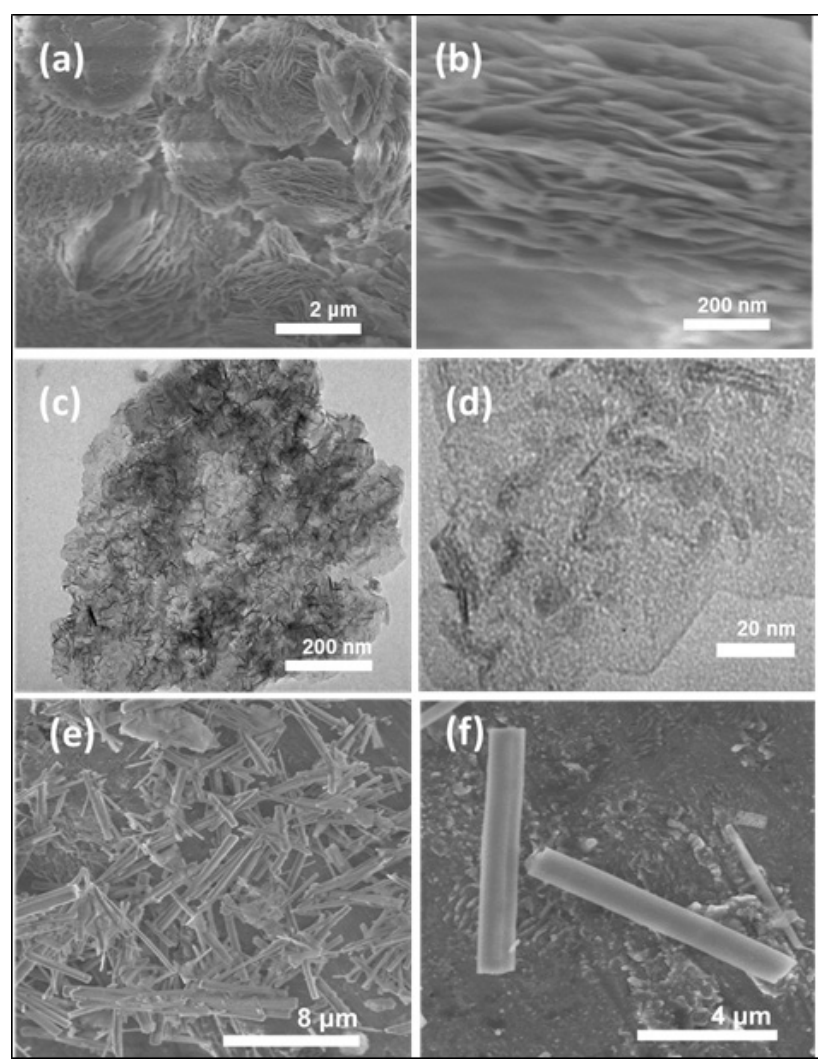

Figure 2. (a-b) and (e-f) the FE-SEM images of F-MgO and $\mathrm{R}-\mathrm{MgO}$ at the different scale bar, (c) and (d) the TEM images of F-MgO.

deformation vibrations ${ }^{28}$. The bands near $1100 \mathrm{~cm}^{-1}$ belongs to $\mathrm{M}-\mathrm{OH}^{29}$. The stretching vibrations $\frac{30}{}$ of the $\mathrm{Mg}-\mathrm{O}$ bands were observed around around 870 and 600 $\mathrm{cm}^{-1}$ while their bending modes were located at $440 \mathrm{~cm}^{-1}$.

The FE-SEM and TEM images of the as-prepared $\mathrm{MgO}$ samples are presented in Figure 2. The morphology of $\mathrm{F}-\mathrm{MgO}$ was hierarchical flower shape with the approximate diameter of $2-5 \mu \mathrm{m}$, in Figures 2(a-b). The flower-like $\mathrm{MgO}$ was made up of a number of nano-sheets with the thickness of $10 \mathrm{~nm}$. In addition, $\mathrm{MgO}$ particles approximately of $10-15 \mathrm{~nm}$ in size were observed in Figures 2(c-d). These results were compatible with XRD and BET results. While, the uniform rod-like $\mathrm{MgO}$ with the smooth surface and the approximately of 4-6 $\mu \mathrm{m}$ in length and $0.5 \mu \mathrm{m}$ in width were observed in Figures 2(e-f).

\subsection{Adsorption of Tartrazine}

\subsubsection{Effect of Contact Time}

The relation of adsorption efficiency for pollutants from aqueous solution of adsorbent versus time is important 
to the design and optimization of an adsorption system. Figure 3 shows the representative plots of adsorption of tartrazine on as-prepared $\mathrm{MgO}$ samples, $\mathrm{CM}-\mathrm{MgO}$ and AC. The adsorption conditions are: adsorbent $0.12 \mathrm{~g}, 100$ $\mathrm{mL}$ of tartrazine $50 \mathrm{mg} / \mathrm{L}$, solution $\mathrm{pH}$ of 7.0 , and temperature $30^{\circ} \mathrm{C}$.

The adsorption tratrazine on $\mathrm{F}-\mathrm{MgO}$ and $\mathrm{CM}-\mathrm{MgO}$ showed a similar trend, the saturation could be approached in initial $10 \mathrm{~min}$. However, the removal efficiency of tartrazine on $\mathrm{CM}-\mathrm{MgO}$ in $80 \mathrm{~min}$ was lower than that of F-MgO. It was compatible to results of BET surface areas of the $\mathrm{F}-\mathrm{MgO}$ and $\mathrm{CM}-\mathrm{MgO}$ samples. The adsorption of tartrazine on $\mathrm{R}-\mathrm{MgO}$ and $\mathrm{AC}$ tended to be similar, gradually increasing with time. In addition, all the MgO samples had higher removal efficiency of tartrazine than that of AC even though surface area of $\mathrm{MgO}$ was much lower than that of AC, in Table 2. These results revealed that the adsorption rate related to the pore size distribution, while the removal efficiency was depended on the surface area with the exception for AC.

For the adsorption of tartrazine on F-MgO with contact time of $15 \mathrm{~min}$, the solution became colourless. The slight yellow was observed for the $\mathrm{R}-\mathrm{MgO}$ and $\mathrm{CM}-\mathrm{MgO}$ samples. And, the colour was almost did not change for AC. The removal efficiencies ofF-MgO, R-MgO, $\mathrm{CM}-\mathrm{MgO}$, and $\mathrm{AC}$ in $15 \mathrm{~min}$ were 99.1, 74.9, 67.0 and $26.7 \%$, respectively. This result indicated that the potential application of F-MgO for wastewater dye treatment, and the F-MgO sample was used to further study. Since, the adsorption tartrazine on $\mathrm{F}-\mathrm{MgO}$ reached saturation in $15 \mathrm{~min}$. The optimal contact time was considered to be 15 min for further study.

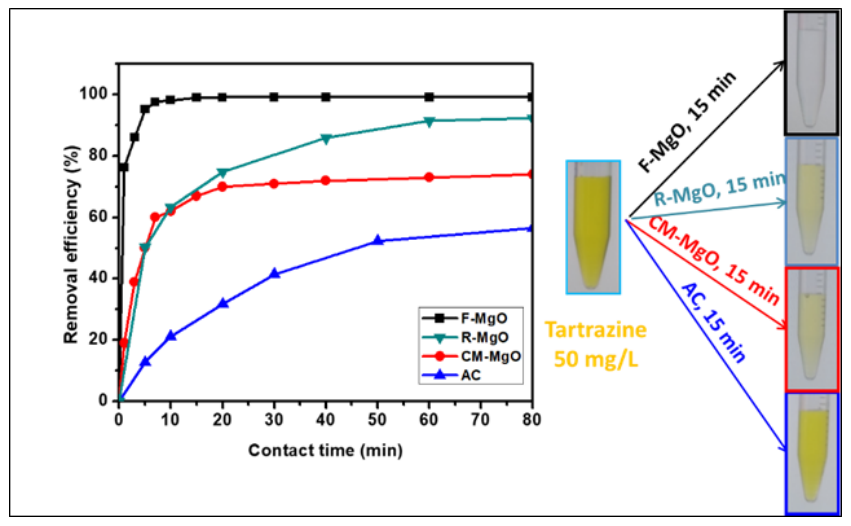

Figure 3. Adsorption of tartrazine on as-prepared $\mathrm{MgO}$ samples, CM-MgO and AC.

\subsubsection{Effect of F-MgO Dosage}

Amount of adsorbent for adsorption of dyes in aqueous solution relating to interaction between them was very important parameter to design of an adsorption system. $\mathrm{MgO}$ dosage was varied form $0.02-0.2 \mathrm{~g}$, while other conditions were remained constant (tratrazine $50 \mathrm{mg} / \mathrm{L}$, solution $\mathrm{pH}=7.0$, contact time $=15 \mathrm{~min}$, and temperature $=30^{\circ} \mathrm{C}$ ). The removal efficiency in $15 \mathrm{~min}$ was calculated as equation (2). The results are shown in Figure 4.

It can be seen that the removal efficiency increased from 40.7 and $99.3 \%$ when $\mathrm{MgO}$ dosage increased from 0.02 to $0.12 \mathrm{~g}$. However, further increasing in dosage of $\mathrm{MgO}$ from 0.12 to $0.2 \mathrm{~g}$ the removal efficiency almost did not changed. The increase in adsorbent dosage led to increase in active site therefore the removal efficiency increased. However, too more active sites exceeding the demand of the saturated adsorption made a large number of effective active sites not used resulting in the saturation of adsorption. Thus, the optimal dosage of $\mathrm{MgO}$ for removing tartrazine was selected to be $0.12 \mathrm{~g}$ for next experiments.

\subsubsection{Effect of Initial Dye Concentration}

The concentration of tartrazine was varied from 20 to $70 \mathrm{mg} / \mathrm{L}$, while other experiment parameters were kept constant $(\mathrm{MgO}$ dosage $=0.12 \mathrm{~g}$, contact time $=15 \mathrm{~min}$, solution $\mathrm{pH}=7.0$ and temperature $=30^{\circ} \mathrm{C}$ ). The results are presented in Figure 5. The dye removal efficiency was slightly decreased when initial dye concentration increased from 20 to $60 \mathrm{mg} / \mathrm{L}$, but it was significantly decreased when dyes concentration increased up to $70 \mathrm{mg} / \mathrm{L}$. The main reason for the reduction of removal efficiency may assign to the large number of tartrazine molecules compared to lack of available adsorption sites on $\mathrm{MgO}$.

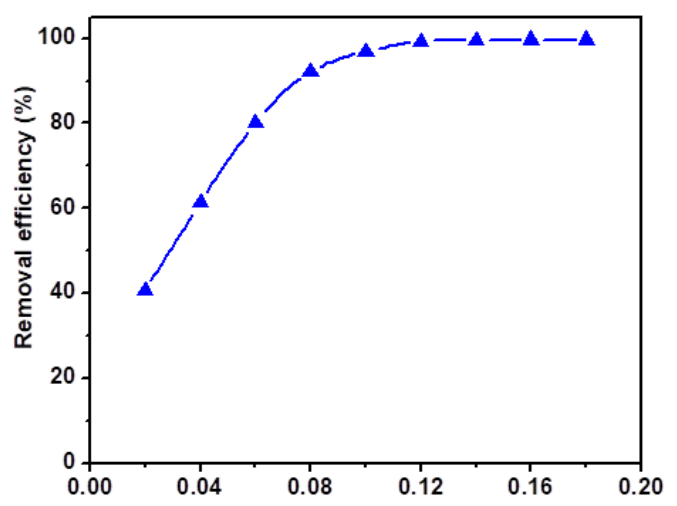

Figure 4. Effect of dosage of F-MgO on adsorption of tartrazine. 


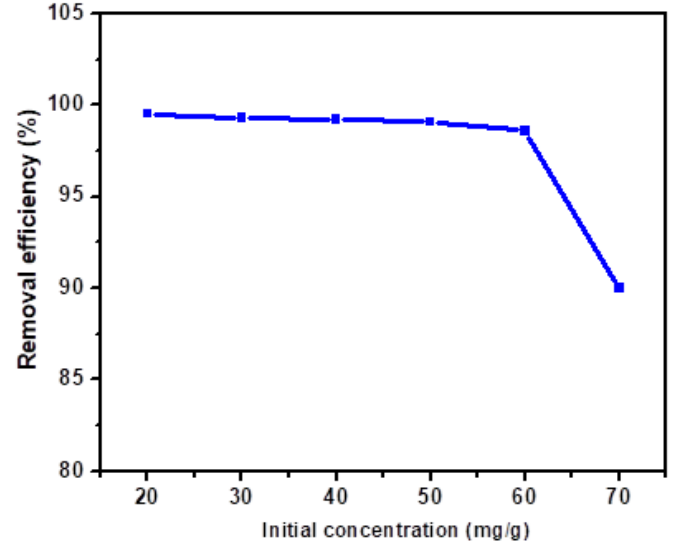

Figure 5. Effect of initial concentration on adsorption of tartrazine.

\subsubsection{Effect of Solution $\mathrm{pH}$}

The $\mathrm{pH}$ in solution is a crucial parameter in adsorption process. It significantly affects not only the functional groups and surface charges of adsorbents, but also the structure and ionization degree of pollutant molecules ${ }^{31}$. The $\mathrm{pH}$ values in range of 3.0-12.0 were used to studied effect of solution $\mathrm{pH}$ on adsorption of tartrazine, while other conditions were remained at constant (dosage of $\mathrm{F}-\mathrm{MgO}=0.12 \mathrm{~g}, 50 \mathrm{mg} / \mathrm{L}$ of tartrazine, contact time $=15$ min, and temperature $=30^{\circ} \mathrm{C}$ ), the results are shown in Figure 6. When $\mathrm{pH}$ solution increased from 3.0 to 9.0, the removal efficiency of tartrazine was almost no changed; it was slightly decrease from 98.3 to $97.5 \%$ when $\mathrm{pH}$ increased from 9.0 to 11.0. However, it significantly affected to adsorption of tartrazine at the high solution $\mathrm{pH}$ value, the removal efficiency was sharply decreased to $70.0 \%$ at solution $\mathrm{pH}=13.0$.

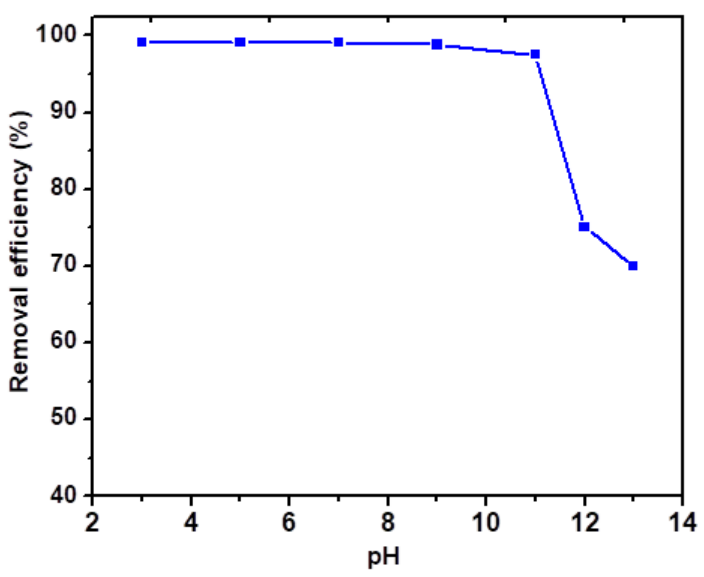

Figure 6. Effect of solution $\mathrm{pH}$ on adsorption of tartrazine on $\mathrm{MgO}$.
In aqueous solution, tartrazine was dissolved in water, the sulfonate group of the tartrazine was dissociated and converted to anionic dye ions $\left(\right.$ dye- $\mathrm{SO}_{3} \mathrm{Na} \rightarrow$ dye- $\mathrm{SO}_{3}^{-}+\mathrm{Na}^{+}$). In addition, at $\mathrm{pH}$ value lower than $\mathrm{pH}_{\mathrm{zpc}}(12.4)^{32}$, hydrous oxide $(-\mathrm{Mg}-\mathrm{OH})$ could converted to $-\mathrm{Mg}-\mathrm{OH}_{2}^{+}\left(-\mathrm{Mg}-\mathrm{OH}+\mathrm{H}^{+} \rightarrow-\mathrm{Mg}-\mathrm{OH}_{2}^{+}\right)$. Therefore, electrostatic attraction between the dye molecules (negative charge) and $\mathrm{MgO}$ surface (positive charge) was the reason for the high removal efficiency. At $\mathrm{pH}$ value higher than $\mathrm{pH}_{\mathrm{zpc}}$, hydrous oxide was deprotonated $\left(-\mathrm{Mg}-\mathrm{OH}+\mathrm{OH}^{-} \rightarrow-\mathrm{Mg}^{-} \mathrm{O}^{-}+\mathrm{H}_{2} \mathrm{O}\right)$. The repulsion force at $\mathrm{pH}=12$ led to sharply reduce the adsorption ability of $\mathrm{MgO}$.

\subsection{Adsorption Isotherms}

The adsorption capacity was fitted with the Langmuir, Freundlich, Temkin, and Dubinin-radushkevich (D-R) isotherm models. The results are presented in Figure 7 and Table 3. It is obvious that the correlations $\left(\mathrm{R}^{2}\right)$ of isotherms are in the order: Langmuir (0.999) > Temkin $(0.989)>$ Freundlich (0.984) $>$ D-R (0.983). It may be concluded that the Langmuir model is suitable to describe the adsorption of tartrazine on mesoporous $\mathrm{MgO}$, which emphasize the formation of monolayer coverage of tartrazine molecules at specific homogenous site on $\mathrm{MgO}$ surface. The $\mathrm{n}$ value $(\mathrm{n}=2)$ in Freundlich isotherm indicated favourable nature of adsorption $\frac{33}{}$. The $\mathrm{E}$ value of $\mathrm{D}-\mathrm{R}$ model, calculated is $4.03 \mathrm{~mol} / \mathrm{kJ}$, confirmed the adsorption is physical process in nature.

Table 3. Adsorption isotherm parameters of tartrazine on $\mathrm{F}-\mathrm{MgO}$

\begin{tabular}{|c|c|c|c|}
\hline Isotherm & Parameter & Value & $\mathbf{R}^{2}$ \\
\hline \multirow[t]{3}{*}{ Langmuir } & $\mathrm{q}_{\max }(\mathrm{mg} / \mathrm{g})$ & 65.8 & \multirow{3}{*}{0.999} \\
\hline & $\mathrm{k}_{\mathrm{L}}$ & 3.56 & \\
\hline & $\mathrm{R}_{\mathrm{L}}$ & 0.004 & \\
\hline \multirow[t]{2}{*}{ Freundlich } & $\mathrm{k}_{\mathrm{F}}$ & 55 & \multirow{2}{*}{0.984} \\
\hline & $\mathrm{n}$ & 2.0 & \\
\hline \multirow[t]{3}{*}{ Temkin } & $\alpha$ & 31.4 & \multirow{3}{*}{0.989} \\
\hline & $\beta$ & 15.3 & \\
\hline & $\mathrm{b}(\mathrm{J} / \mathrm{mg})$ & 164.8 & \\
\hline \multirow[t]{3}{*}{ D-R } & $\mathrm{K}\left(\mathrm{mol}^{2} / \mathrm{kJ}^{2}\right)$ & 0.03 & \multirow{3}{*}{0.983} \\
\hline & $\mathrm{Q}_{\mathrm{m}}(\mathrm{mol} / \mathrm{g})$ & 50.9 & \\
\hline & $\mathrm{E}(\mathrm{kJ} / \mathrm{mol})$ & 4.08 & \\
\hline
\end{tabular}



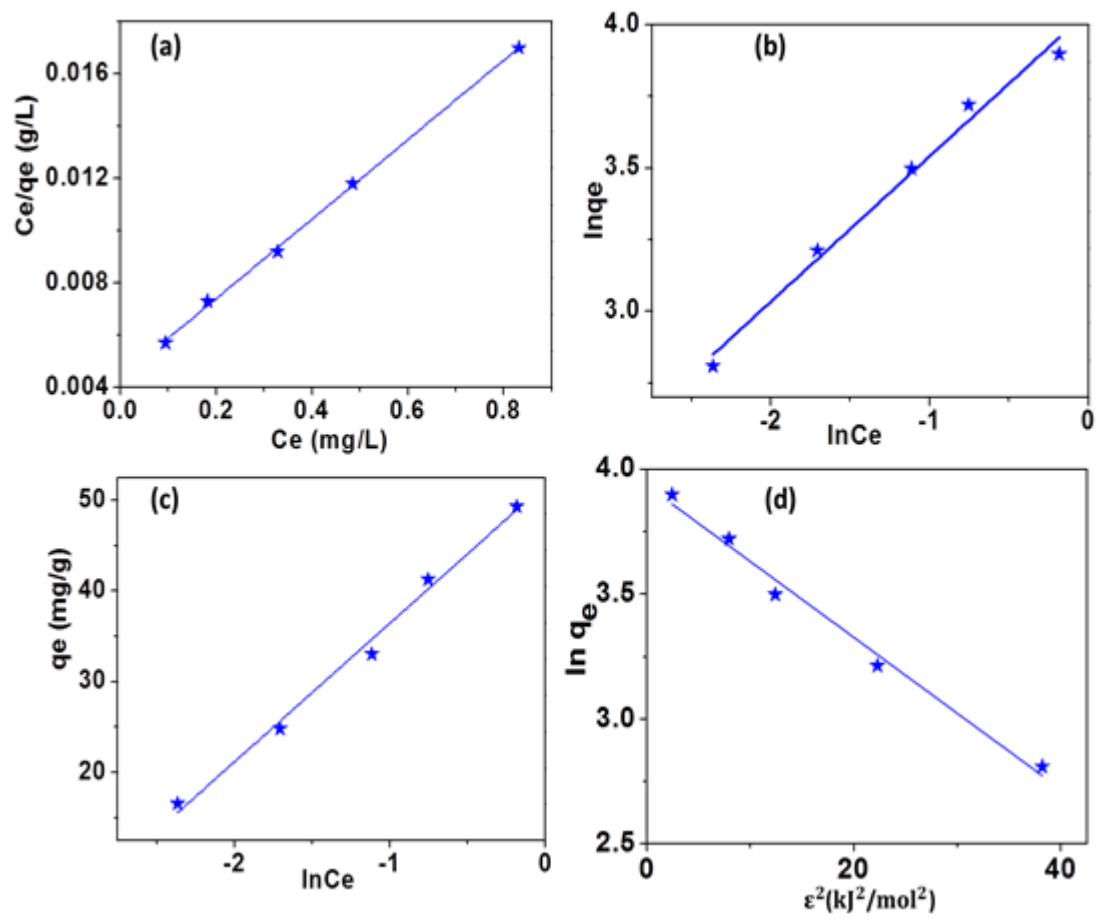

Figure 7. The fitting plots of adsorption of tartrazine on F-MgO by (a) Langmuir, (b) Freundlich, (c) Temkin, and (d) D-R isotherm models.

The essential feature of the Langmuir isotherm may be express in term of dimensionless separation factor $R_{L}$ which is given by the following equation:

$$
R_{L}=\frac{1}{1+K_{L} C_{o}}
$$

Where $\mathrm{C}_{\mathrm{o}}$ is the initial dye concentration and is the Langmuir adsorption constant $(\mathrm{L} / \mathrm{mg})$. As the result, the value of $R_{L}$ was 0.004 indicating favorable adsorption of tartrazine on $\mathrm{F}-\mathrm{MgO}$ particles ${ }^{34}$

The maximum adsorption capacity of $\mathrm{F}-\mathrm{MgO}$ was compared to other sorbents in Table 4. Since each study evaluated removal capacity under different conditions, direct comparison among catalysts is challenging, but the relative performance of adsorbent can be evaluated indirectly. The F-MgO samples had high maximum adsorption capacity $(65.8 \mathrm{mg} / \mathrm{g})$ as compared to other adsorbents such as $\mathrm{MgO}, \mathrm{AC}$, sawdust, chitin, bottom ash, commercial activated carbon, polyaniline nano layer composite, hen feather, amberlite IRA-910, and carbon nano-tube, their maximum monolayer adsorption capacities in range of $2.47-59.1 \mathrm{mg} / \mathrm{g}$. The reason for high adsorption capacity of F-MgO compare to other sorbents could be attributed to either specific surface area, pore size and pore volume of $\mathrm{MgO}$ or hierarchical structure flower-like $\mathrm{MgO}$ which is suitable to take up tartrazine molecules from aqueous solution.

Table 4. The adsorption capacity of tartrazine on as prepared $\mathrm{MgO}$ samples and referred adsorbents

\begin{tabular}{|l|c|c|}
\hline \multicolumn{1}{|c|}{ Adsorbent } & $\begin{array}{c}\text { Maximum } \\
\text { adsorption capacity } \\
\text { (mg/g) }\end{array}$ & Reference \\
\hline F-MgO & 65.8 & This work \\
\hline R-MgO & 59.1 & This work \\
\hline AC & 41.5 & This work \\
\hline CM-MgO & 32.6 & This work \\
\hline Sawdust & 4.71 & $\underline{36}$ \\
\hline Chitin & 30.0 & $\underline{37}$ \\
\hline Bottom ash & 12.6 & $\underline{38}$ \\
\hline $\begin{array}{l}\text { Commercial } \\
\text { activatedcarbon }\end{array}$ & 4.48 & $\underline{39}$ \\
\hline $\begin{array}{l}\text { Polyaniline nano layer } \\
\text { composite }\end{array}$ & 2.47 & $\underline{40}$ \\
\hline Hen feather & 64.10 & $\underline{41}$ \\
\hline Amberlite IRA-910 & 49.96 & $\underline{42}$ \\
\hline Carbon nano-tube & 52.24 & 43 \\
\hline
\end{tabular}




\subsection{Adsorption Kinetic}

The plots of fitting and the kinetic parameters are presented in Figure 8 and Table 5, respectively. The regression coefficient $\left(\mathrm{R}^{2}\right)$ of pseudo-second-order model was larger than those pseudo-first-order and Elovich models. It revealed that the pseudo-second-order kinetic was better in describing the adsorption kinetic of tartrazine on $\mathrm{MgO}$. Two linear plots of $\mathrm{q}_{\mathrm{t}}$ versus $\mathrm{t}^{0.5}$ for experiment data, in Figure 8(c), and the values of $\mathrm{k}_{\mathrm{i}}$ and $\mathrm{C}$ were summarized in Table 5 indicated the adsorption process was controlled by two steps. The first linear in diffusion model can be contributed to the mass transfer of adsorbates molecule from the bulk solution to the adsorbent surface. The later linear may exhibit the slow diffusion process of dye molecules from surface site into the inner pores. In addition, the linear plots of $q_{t}$ versus $t^{0.5}$ did not pass through the origin, meaning the boundary layer diffusion was the rate controlling step in the process of adsorption of dye on $\mathrm{F}-\mathrm{MgO}$.
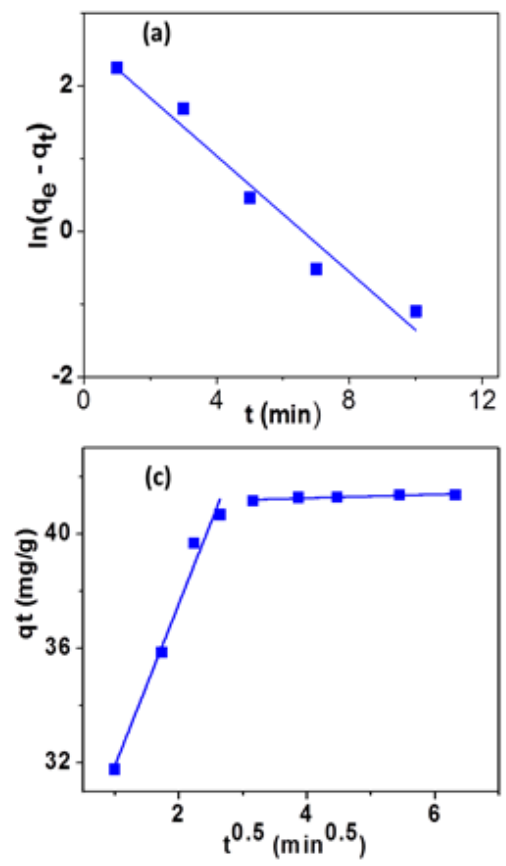

Table 5. Kinetics parameters for the adsorption of tartrazine on $\mathrm{F}-\mathrm{MgO}$

\begin{tabular}{|c|c|c|}
\hline Model & Parameter & Value \\
\hline \multirow[t]{4}{*}{ Pseudo-first-order } & $\mathrm{q}_{e, \exp }\left(\mathrm{mg} \cdot \mathrm{g}^{-1}\right)$ & 41.3 \\
\hline & $\mathrm{q}_{e, \text { cal }}\left(\mathrm{mg} \cdot \mathrm{g}^{-1}\right)$ & 13.9 \\
\hline & $\mathrm{k}_{1}\left(\min ^{-1}\right)$ & 0.4 \\
\hline & $\mathrm{R}^{2}$ & 0.952 \\
\hline \multirow[t]{3}{*}{ Pseudo-second-order } & $\mathrm{q}_{\mathrm{e}, \mathrm{cal}}\left(\mathrm{mg} \cdot \mathrm{g}^{-1}\right)$ & 58.8 \\
\hline & $\mathrm{k}_{2}\left(\mathrm{~g} \cdot \mathrm{mg}^{-1} \cdot \mathrm{min}^{-1}\right)$ & 0.02 \\
\hline & $\mathrm{R}^{2}$ & 0.998 \\
\hline \multirow{6}{*}{$\begin{array}{l}\text { Intra-particle } \\
\text { diffusion }\end{array}$} & $\mathrm{k}_{1}$ & 5.65 \\
\hline & $\mathrm{C}_{1}\left(\mathrm{mg} \cdot \mathrm{mg}^{-1 / 2} \cdot \mathrm{g}^{-1}\right)$ & 26.23 \\
\hline & $\mathrm{R}_{1}^{2}$ & 0.971 \\
\hline & $\mathrm{k}_{2}$ & 0.06 \\
\hline & $\mathrm{C}_{2}\left(\mathrm{mg} \cdot \mathrm{mg}^{-1 / 2} \cdot \mathrm{g}^{-1}\right)$ & 40.6 \\
\hline & $\mathrm{R}_{2}^{2}$ & 0.999 \\
\hline \multirow[t]{3}{*}{ Elovich } & $\alpha\left(\mathrm{mg} \cdot \mathrm{mg}^{-1} \cdot \mathrm{g}^{-1}\right)$ & 0.39 \\
\hline & $\beta\left(\mathrm{mg} . \mathrm{g}^{-1}\right)$ & 1522 \\
\hline & $\mathrm{R}^{2}$ & 0.769 \\
\hline
\end{tabular}
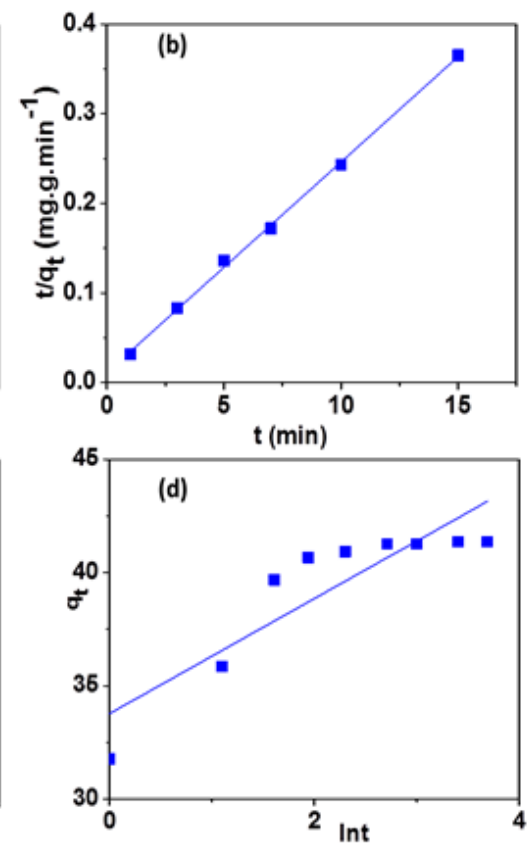

Figure 8. Fitting plots of (a) Pseudo-first-orde, (b) pseudo- second-order, (c) intra-particle diffusion, and (d) Elovich models. 


\subsection{Thermodynamic}

The values of thermodynamic parameters have a great meaning for practical application for an adsorption process. Figure 9 shows the plots of effect of temperature on adsorption capacity and Van'th off equation for adsorption of tartrazine on $\mathrm{MgO}$. In addition, the values of thermodynamic parameters were calculated are shown in Table 6.
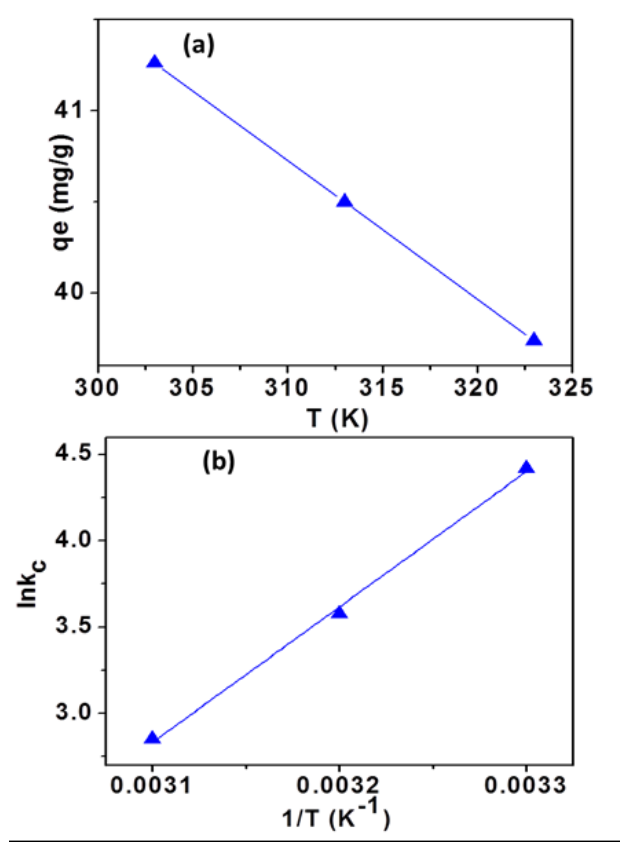

Figure 9. (a) Effect of temperature on adsorption capacity of tartrazine, (b) Van'th off plot for the adsorption of tartrazine on F-MgO.

Table 6. Thermo-dynamic parameters for the adsorption of tartrazine on $\mathrm{MgO}$

\begin{tabular}{|c|c|c|c|c|}
\hline $\begin{array}{c}\text { Temperature } \\
(\mathbf{K})\end{array}$ & $\begin{array}{c}\Delta \mathbf{G}^{\circ} \\
\left(\mathbf{K J}^{\circ} \cdot \mathbf{m o l}^{-1}\right)\end{array}$ & $\begin{array}{c}\Delta \mathbf{H}^{\circ} \\
\left(\mathbf{K J}^{\circ} \cdot \mathbf{m o l}^{-1}\right)\end{array}$ & $\begin{array}{c}\Delta \mathbf{S}^{\circ} \\
\left(\mathbf{J}^{\circ} \cdot \mathbf{K}^{-1} \cdot \mathbf{m o l}^{-1}\right)\end{array}$ & $\mathbf{k}_{\mathbf{c}}$ \\
\hline 303 & -9.37 & -19.78 & -0.03 & 83.1 \\
\hline 313 & -8.76 & & & 35.9 \\
\cline { 1 - 2 } \cline { 5 - 5 } & -0.94 & & & 17.3 \\
\hline 323 & & &
\end{tabular}

As presented in Figure 9 and Table 6, the adsorption capacity and adsorption rate $\left(k_{c}\right)$ weredecreased when the temperature increased. The negative value of: $\Delta \mathrm{H}^{\circ}$ $\left(-19.78 \mathrm{~kJ} \cdot \mathrm{mol}^{-1}\right)$, revealed the exothermic adsorption of tartrazine on $\mathrm{MgO}$ innature and the negative value of $\Delta \mathrm{S}^{\circ}$ $\left(-0.03 \mathrm{~J} \cdot \mathrm{k}^{-1} \cdot \mathrm{mol}^{-1}\right)$ suggested the decrease in the degree of freedom of the adsorbed species. The $\Delta \mathrm{G}^{\circ}$ values were negative implying the adsorption process of tartrazine on $\mathrm{MgO}$ was spontaneous in nature ${ }^{35}$. The $\Delta \mathrm{G}^{\circ}$ value was decreased when the temperature increased suggesting the less favorable adsorption at higher temperature.

\subsection{Regeneration of F-MgO}

The reusability of catalyst is one of important factors from industrial perspective. In this study, the reusable potential of the F-MgO sample was evaluated by removal efficiency through five consecutive cycles. After an experiment, $\mathrm{MgO}$ was recovered from solution and then calcined at $500^{\circ} \mathrm{C}$ under are flow for $4 \mathrm{~h}$. The $\mathrm{MgO}$ sample was used for the next experiment in the same conditions. According to Figure 10, regenerated adsorbent could retain the high removal efficiency in five successive cycles. The removal efficiency was gradually decreased, but it still remained at $95.2 \%$ for the fifth experiment.

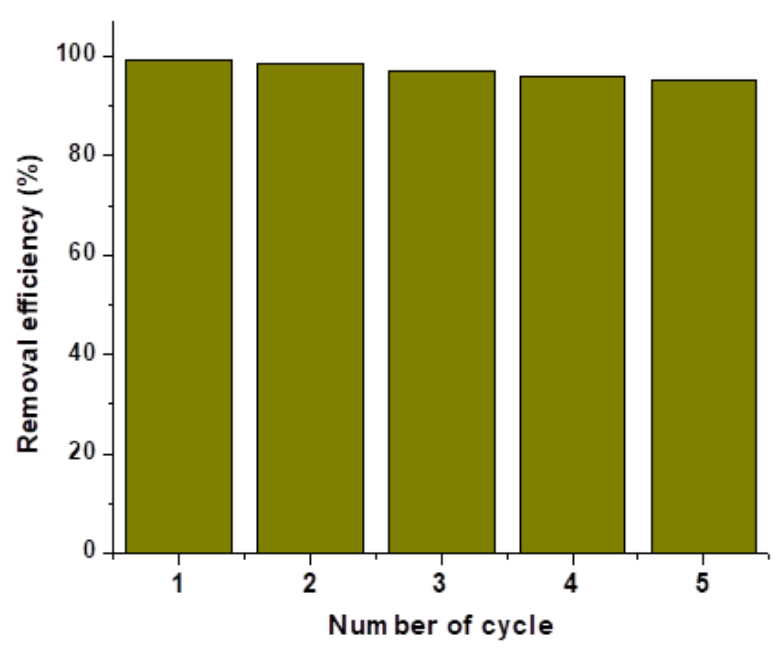

Figure 10. Removal efficiency of tartrazine F-MgO sample in five successive cycles, reaction conditions: dosage of $\mathrm{F}-\mathrm{MgO}=0.12 \mathrm{~g}$, tartrazine concentration $=50 \mathrm{mg} / \mathrm{L}$, contact time $=15 \mathrm{~min}, \mathrm{pH}=7.0$, and temperature $=30^{\circ} \mathrm{C}$ ).

\subsection{Adsorption of Different Organic Dyes on $\mathrm{F}-\mathrm{MgO}$}

The removal efficiency of dyes depend not only adsorbent behaviour such as surface area, pore volume and pore size distribution, and reaction parameters but also properties of dyes. Each adsorbent might have optimum condition for adsorption of dye. Beside to tartrazine, in this study, the performance of $\mathrm{F}-\mathrm{MgO}$ was evaluated by adsorption of other organic dyes such as alizarin, alcian blue, methylene blue, and janus green $\mathrm{B}$ at the optimal 
conditions for tartrazine: $\mathrm{F}-\mathrm{MgO}$ dosage $=0.12 \mathrm{~g}$, initial dye concentration $=50 \mathrm{mg} / \mathrm{L}, \mathrm{pH}=7.0$, and temperature $=30^{\circ} \mathrm{C}$. The results are shown in Figure 11. F-MgO had the low adsorption ability for methylene blue, its removal efficiency was $18.4 \%$, while it showed a good adsorption of tartrazine, alizarin, alcian blue, and janus green $\mathrm{B}$, the removal efficiencies at 80 min were $99.3,96.6,97.7$ and $72.1 \%$, respectively.

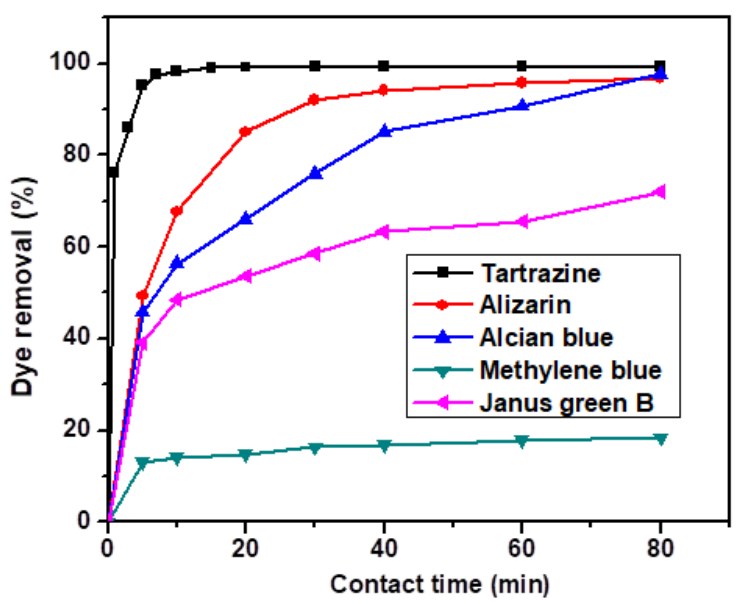

Figure 11. Adsorption of different dyes on F-MgO (dosage of $\mathrm{F}-\mathrm{MgO}=0.12 \mathrm{~g}, \mathrm{pH}=7.0$, and temperature $=30^{\circ} \mathrm{C}$ ).

\subsection{Removal of $\mathrm{Pb}$ (II) by F-MgO/Tartrazine}

As shown in Figure 12, the removal efficiency of $\mathrm{Pb}$ (II) on $\mathrm{F}-\mathrm{MgO}$ was small. It was about $10 \%$ within $120 \mathrm{~min}$. Whereas, it could be observed that tartrazine adsorbed on surface of $\mathrm{MgO}$ worked as coupling agent, leading an increase in adsorption of $\mathrm{Pb}$ (II), the removal efficiency and adsorption capacity in $120 \mathrm{~min}$ were $95 \%$ and 47.5 $\mathrm{mg} / \mathrm{g}$, respectively. The reason of high adsorption capacity of $\mathrm{Pb}$ (II) on $\mathrm{MgO} /$ tartrazine could be attributed to either surface charge of adsorbent or formation of stable complexes. As presented in section 3.2.4, the surface charge of $\mathrm{MgO}$ was positive at $\mathrm{pH}=6.0$, the repulsion force between $\mathrm{MgO}$ and lead (II) led the decrease in adsorption capacity. Whereas, for $\mathrm{MgO}$ adsorbed tartrazine ( $\mathrm{MgO} /$ tartrazine), positive charge on surface $\mathrm{MgO}$ could cooperate with negative group of tartrazine $\left(-\mathrm{SO}_{3}^{-}\right)$ to form double layer on the surface of particles, leading to reduction of repulsion and increase in adsorption capacity. The second reason could be assigned to the formation of stable complexes between lead (II) with tartrazine adsorbed on surface of $\mathrm{MgO}$, this enhanced the accumulation of metal ion on $\mathrm{MgO} /$ tartrazine.

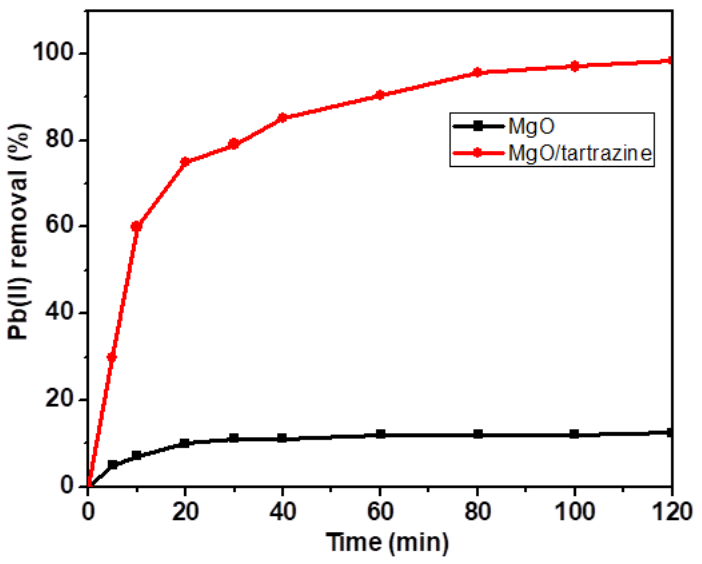

Figure 12. Adsorption of $\mathrm{Pb}(\mathrm{II})$ on $\mathrm{F}-\mathrm{MgO}$ and $\mathrm{F}-\mathrm{MgO} /$ tartrazine.

\section{Conclusion}

$\mathrm{MgO}$ samples with different morphologies were prepared by a facile precipitation method for enhanced adsorptions of tartrazine and $\mathrm{Pb}$ (II). The F-MgO sample had the large surface area $\left(232 \mathrm{~m}^{2} / \mathrm{g}\right)$ and high pore volume $\left(0.575 \mathrm{~cm}^{2} / \mathrm{g}\right)$ as compared to R-MgO $\left(145 \mathrm{~m}^{2} / \mathrm{g}\right.$ and 0.263 $\left.\mathrm{m}^{3} / \mathrm{g}\right)$ and CM-MgO $\left(103 \mathrm{~m}^{2} / \mathrm{g}\right.$ and $\left.0.421 \mathrm{~m}^{3} / \mathrm{g}\right)$. At the optimal condition (adsorbent dosage $=0.12 \mathrm{~g}, 100 \mathrm{~mL}$ of tartrazine $50 \mathrm{mg} / \mathrm{L}$, solution $\mathrm{pH}=7.0$, temperature $=$ $30^{\circ} \mathrm{C}$, and contact time $\left.=15 \mathrm{~min}\right) . \mathrm{F}-\mathrm{MgO}$ had a higher removal efficiency of dye than $\mathrm{R}-\mathrm{MgO}, \mathrm{CM}-\mathrm{MgO}$ and $\mathrm{AC}$. The reason for high adsorption capacity of F-MgO compare to other sorbents could be attributed to either specific surface area, pore size and pore volume of $\mathrm{MgO}$ or hierarchical structure flower-like $\mathrm{MgO}$ which is suitable to take up tartrazine molecules from aqueous solution, but the adsorption rate was influenced from pore size distribution of adsorbent. The experimental equilibrium data was well described by Langmuir isotherm with $\mathrm{R}^{2}$ of 0.999 . The adsorption kinetic studies showed better applicability for pseudo-second-order model. The adsorption was found to be spontaneous and exothermic as evidenced by the thermodynamic parameters. After 5 consecutive experiments, the removal efficiency was still remained at $95.2 \%$. In addition, F-MgO could also remove other dyes such as alizarin, alcian blue, methylene blue, and janus green $\mathrm{B}$ with the considerable adsorption capacities. Particularly, tartrazine adsorben on surface of $\mathrm{MgO}$ led to reduce the repulsion force of $\mathrm{MgO}$ with lead (II) and formation of complexes between metal ions with tartrazine this improved the sorption capacity of lead (II) on $\mathrm{MgO} /$ tartrazine ( $47.5 \mathrm{mg} / \mathrm{g}$ ). 


\section{Acknowledgments}

This work was supported by Vietnamese Ministry of Education and Training under grant number B2017BKA-53.

\section{References}

1. Guo Y, Deng J, Zhu J, Zhou X, Bai R. Removal of mercury (ii) and methylene blue from a wastewater environment with magnetic graphene oxide: Adsorption kinetics, isotherms and mechanism, RSC Advances. 2016, 86:82523-36. https://doi.org/10.1039/C6RA14651A.

2. Kumar N, Reddy L, Parashar V, Ngila JC. Controlled synthesis of micro-sheets of $\mathrm{ZnAl}$ layered double hydroxides hexagonal nano-plates for efficient removal of $\mathrm{Cr}(\mathrm{VI})$ ions and anionic dye from water, Journal of Environmental Chemical Engineering. 2017; 5(2):1718-31. https://doi. org/10.1016/j.jece.2017.03.014.

3. Wang S, Ariyanto E. Competitive adsorption of malachite green and $\mathrm{Pb}$ ions on natural zeolite, Journal of Colloid and Interface Science. 2007; 314(1):25-31. https://doi. org/10.1016/j.jcis.2007.05.032. PMid: 17543322.

4. Holkar CR, Jadhav AJ, Pinjari DV, Mahamuni NM, Pandit AB. A critical review on textile waste water treatments: Possible approaches, Journal of Environmental Management. 2016; 182:351-66. https://doi.org/10.1016/j. jenvman.2016.07.090. PMid: 27497312.

5. Venkatesha TG, Viswanatha R, Arthoba Nayaka Y, Chethana BK. Kinetics and thermodynamics of reactive and vat dyes adsorption on $\mathrm{MgO}$ nano-particles, Chemical Engineering Journal. 2012; 198-99:1-10. https://doi. org/10.1016/j.cej.2012.05.071.

6. Anantha RK, Kota S. Removal of lead by adsorption with the renewable biopolymer composite of feather (Dromaius novaehollandiae) and chitosan (Agaricus bisporus), Environmental Technology and Innovation. 2016; 6:11-26. https://doi.org/10.1016/j.eti.2016.04.004.

7. Järup L. Hazards of heavy metal contamination, British Medical Bulletin. 2003; 68(1):167-82. https://doi.org/10.1093/bmb/ldg032. PMid: 14757716.

8. Gode F, Pehlivan E. Removal of chromium (III) from aqueous solutions using Lewatit S 100: The effect of $\mathrm{pH}$, time, metal concentration and temperature, Journal of Hazardous Materials. 2006; 136(2):330-37. https://doi.org/10.1016/j. jhazmat.2005.12.021. PMid: 16439060.

9. Mohsen-Nia M, Montazeri P, Modarress H. Removal of $\mathrm{Cu} 2+$ and $\mathrm{Ni} 2+$ from wastewater with a chelating agent and reverse osmosis processes, Desalination. 2007; 217(13):276-81. https://doi.org/10.1016/j.desal.2006.01.043.
10. Landaburu-Aguirre J, Pongrácz E, Perämäki P, Keiski RL. Micellar-enhanced ultra-filtration for the removal of cadmium and zinc: Use of response surface methodology to improve understanding of process performance and optimization, Journal of Hazardous Materials. 2010; 180(1-3):524-34. https://doi.org/10.1016/j.jhazmat.2010.04.066. PMid: 20488619.

11. Oke IA, Lukman S, Ismail A, Fehintola EO, Amoko JS. 19 - Removal of lead ions from water and waste waters electro-chemically A2 - Grumezescu, Alexandru Mihai, Water Purification, Academic Press; 2017. p. 643-91.

12. Hussin F, Abnisa F, Issabayeva G, Aroua MK. Removal of lead by solar-photovoltaic electro-coagulation using novel perforated zinc electrode, Journal of Cleaner Production. 2017; 147:206-16. https://doi.org/10.1016/j. jclepro.2017.01.096.

13. Vu A-T, Jiang S, Kim Y-H, Lee C-H. Controlling the physical properties of magnesium oxide using a calcination method in aerogel synthesis: Its application to enhanced sorption of a sulfur compound, Industrial and Engineering Chemistry Research. 2014; 53(34):13228-35. https://doi. org/10.1021/ie5018546.

14. Mohamed RM, Shawky A, Mkhalid I A. Facile synthesis of $\mathrm{MgO}$ and $\mathrm{Ni}-\mathrm{MgO}$ nanostructures with enhanced adsorption of methyl blue dye, Journal of Physics and Chemistry of Solids. 2017; 101:50-57. https://doi.org/10.1016/j. jpcs.2016.10.009.

15. Mahmoud HR, El-Molla SA, Saif M. Improvement of physicochemical properties of $\mathrm{Fe} 2 \mathrm{O} 3 / \mathrm{MgO}$ nano-materials by hydrothermal treatment for dye removal from industrial waste water, Powder Technology. 2013; 249:225-33. https:// doi.org/10.1016/j.powtec.2013.08.021.

16. Haldorai Y, Shim J-J. An efficient removal of methyl orange dye from aqueous solution by adsorption onto chitosan/MgO composite: A novel reusable adsorbent, Applied Surface Science. 2014; 292:447-53. https://doi. org/10.1016/j.apsusc.2013.11.158.

17. Moussavi G, Mahmoudi M. Removal of azo and anthraquinone reactive dyes from industrial waste waters using $\mathrm{MgO}$ nano-particles, Journal of Hazardous Materials. 2009; 168(2-3):806-12. https://doi.org/10.1016/j. jhazmat.2009.02.097. PMid: 19303210.

18. Kim Y-H, Tuan VA, Park M-K, Lee C-H. Sulfur removal from municipal gas using magnesium oxides and a magnesium oxide/silicon dioxide composite, Micro-porous Meso-porous Materials. 2014; 197:299-307. https://doi. org/10.1016/j.micromeso.2014.06.026.

19. Vu A-T, Jiang S, Ho K, Lee JB, Lee C-H. Meso-porous magnesium oxide and its composites: Preparation, characterization, and removal of 2-chloroethyl ethyl sulfide, 
Chemical Engineering Journal. 2015; 269:82-93. https:// doi.org/10.1016/j.cej.2015.01.089.

20. Langmuir I. The adsorption of gases on plane surfaces of glass, mica and platinum, Journal of the American Chemical Society. 1918; 40(9):1361-403. https://doi. org/10.1021/ja02242a004.

21. Freundlich HMF. Over the adsorption in solution, The Journal of Physical Chemistry. 1906; 57A:385-470.

22. Temkin MI. Kinetics of ammonia synthesis on promoted iron catalyst, Acta Physica-Chimica Sinica. 1940; 12:327-56.

23. Rotte NK, Yerramala S, Boniface J, Srikanth VVSS. Equilibrium and kinetics of Safranin $O$ dye adsorption on $\mathrm{MgO}$ decked multi-layered grapheme, Chemical Engineering Journal. 2014; 258:412-19. https://doi. org/10.1016/j.cej.2014.07.065.

24. Shao Y, Wang X, Kang Y, Shu Y, Sun Q, Li L. Application of Mn/MCM-41 as an adsorbent to remove methyl blue from aqueous solution, Journal of Colloid and Interface Science. 2014; 429:25-33. https://doi.org/10.1016/j.jcis.2014.05.004. PMid: 24935186.

25. Ghaedi M, Rahimi M r, Ghaedi AM, Tyagi I, Agarwal S, Gupta VK. Application of least squares support vector regression and linear multiple regression for modeling removal of methyl orange onto tin oxide nano-particles loaded on activated carbon and activated carbon prepared from Pistacia Atlantica wood, Journal of Colloid and Interface Science. 2016; 461:425-34. https://doi. org/10.1016/j.jcis.2015.09.024. PMid: 26414425.

26. Chien HC. Application of Elovich equation to the kinetics of phosphate release and sorption in soils, Soil Science Society of America Journal. 1980; 44(2):265-68. https:// doi.org/10.2136/sssaj1980.03615995004400020013x.

27. Mironyuk IF, Gun'ko VM, Povazhnyak MO, Zarko VI, Chelyadin VM, Leboda R, Skubiszewska-Zięba J, Janusz W. Magnesia formed on calcination of $\mathrm{Mg}(\mathrm{OH}) 2$ prepared from natural bischofite, Applied Surface Science. 2006; 252(12):4071-82. https://doi.org/10.1016/j. apsusc.2005.06.020.

28. Mahmoud HR, Ibrahim SM, El-Molla SA. Textile dye removal from aqueous solutions using cheap $\mathrm{MgO}$ nanomaterials: Adsorption kinetics, isotherm studies and thermo-dynamics, Advanced Powder Technology. 2016; 27(1):223-31. https://doi.org/10.1016/j.apt.2015.12.006.

29. Dhaouadi $\mathrm{H}$, Touati HCF. $\mathrm{Mg}(\mathrm{OH})_{2}$ nano-rods synthesized by a facile hydrothermal method in the presence of CTAB, Nano-Micro Letters. 2011; 3(3):153-59. https://doi. org/10.1007/BF03353666.

30. Yang X, Li Y, Du Q, Sun J, Chen L, Hu S, Wang Z, Xia Y, Xia L. Highly effective removal of basic fuchsin from aqueous solutions by anionic poly-acrylamide/graphene oxide aerogels, Journal of Colloid and Interface Science. 2015; 453:107-14. https://doi.org/10.1016/j.jcis.2015.04.042. PMid: 25978557.

31. Al-Degs YS, El-Barghouthi MI, El-Sheikh AH, Walker GM. Effect of solution $\mathrm{pH}$, ionic strength, and temperature on adsorption behavior of reactive dyes on activated carbon, Dyes and Pigments. 2008; 77(1):16-23. https://doi. org/10.1016/j.dyepig.2007.03.001.

32. Malik PK. Use of activated carbons prepared from sawdust and rice-husk for adsorption of acid dyes: A case study of Acid Yellow 36, Dyes and Pigments. 2003; 56(3):239-49. https://doi.org/10.1016/S0143-7208(02)00159-6.

33. Malik PK. Dye removal from wastewater using activated carbon developed from sawdust: Adsorption equilibrium and kinetics, Journal of Hazardous Materials. 2004; 113(13):81-88. https://doi.org/10.1016/j.jhazmat.2004.05.022. PMid: 15363517.

34. Kamari A, Ngah WSW, Chong MY, Cheah ML. Sorption of acid dyes onto GLA and $\mathrm{H} 2 \mathrm{SO} 4$ cross-linked chitosan beads, Desalination. 2009; 249:1180-89. https://doi. org/10.1016/j.desal.2009.04.010.

35. Banerjee S, Chattopadhyaya MC. Adsorption characteristics for the removal of a toxic dye, tartrazine from aqueous solutions by a low cost agricultural by-product, Arabian Journal of Chemistry. 2017; 10(2):S1629-38. https://doi. org/10.1016/j.arabjc.2013.06.005.

36. Dotto GL, Pinto AA. Kinetics and Mechanism of tartrazine adsorption onto chitin and chitosan, Industrial and Engineering Chemistry Research. 2012; 51(19):6862-68. https://doi.org/10.1021/ie2030757.

37. Mittal A, Mittal J, Kurup L. Adsorption isotherms, kinetics and column operations for the removal of hazardous dye, Tartrazine from aqueous solutions using waste materialsBottom Ash and De-Oiled Soya, as adsorbents, Journal of Hazardous Materials. 2006; 136(3):567-78. https://doi. org/10.1016/j.jhazmat.2005.12.037. PMid: 16442722 .

38. Jibril M, Poh LS, Evuti AM. Removal of colour from waste water using Coconut Shell Activated Carbon (CSAC) and Commercial Activated Carbon (CAC), Jurnal Teknologi. 2013; 60(1):15-19.

39. Ansari R, Delavar AF. Application of polyaniline nano-layer composite for removal of tartrazine dye from aqueous solutions, Journal of Polymer Research. 2011; 18(6):1931-39. https://doi.org/10.1007/s10965-011-9600-z.

40. Mittal A, Kurup L, Mittal J. Freundlich and Langmuir adsorption isotherms and kinetics for the removal of Tartrazine from aqueous solutions using hen feathers, Journal of Hazardous Materials. 2007; 146(1-2):243-48. https://doi.org/10.1016/j.jhazmat.2006.12.012. PMid: 17222509. 
41. Wawrzkiewicz M, Hubicki Z. Removal of tartrazine from aqueous solutions by strongly basic polystyrene anion exchange resins, Journal of Hazardous Materials. 2009; 164:502-09. https://doi.org/10.1016/j.jhazmat.2008.08.021. PMid: 18809256.
42. Goscianska J, Pietrzak R. Removal of tartrazine from aqueous solution by carbon nano-tubes decorated with silver nano-particles, Catalysis Today. 2015; 249:259-64. https:// doi.org/10.1016/j.cattod.2014.11.017. 